\title{
Antioxidant Indices and Amino Acid Composition of Phenolic Containing Lima Beans (Phaseolus lunatus) After Simulated Human Gastrointestinal Digestion
}

\author{
Sule O. Salawu ${ }^{*}$, b, Oluwaseun M. Folorunso $^{a}$, Akintunde A. Akindahunsia $^{\mathrm{a}}$, And \\ Aline A. BOLIGON ${ }^{c}$ \\ ${ }^{\text {a }}$ Department of Biochemistry, Federal University of Technology, P.M.B. 704, Akure. Nigeria \\ ${ }^{\mathrm{b}}$ Department of Biochemistry, Osun State University, Osogbo, Nigeria \\ ${ }^{\mathrm{c}}$ Universidade Federal de Santa Maria, Centro de Ciências da Saúde, Departamento de Farmácia Industrial, \\ Sala 1115. Campus Camobi. Santa Maria, Rio Grande do Sul. CEP 97105-900 Brasil \\ ${ }^{*}$ Corresponding author \\ sosalawu@futa.edu.ng \\ TEL: +2348132595807
}

Received: 30 June 2018; Published online: 18 April 2019

\begin{abstract}
The present investigation was designed to characterize the phenolic profile of Lima beans (Phaseolus Lunatus) and also to evaluate the antioxidant indices: total phenolic content (TPC), total flavonoid content (TFC), ferric reducing antioxidant power (FRAP), 2,2-Diphenyl-1-picrylhydrazyl (DPPH) radical scavenging activity and amino acid composition at different stages of simulated gastrointestinal digestion (oral, gastric, intestinal). High Performance Liquid Chromatography (HPLC-DAD) analysis revealed the presence of some phenolic compounds (gallic acid, catechin, caffeic acid, rutin, quercitrin, quercetin, kaempferol and apigenin), with a reduced amount $(\mathrm{mg} / \mathrm{g}$ ) after cooking: gallic acid (raw: $1.96 \pm 0.02$; cooked: $1.82 \pm 0.01$ ); catechin (raw: $0.83 \pm 0.01$; cooked: $0.73 \pm 0.01$ ); rutin (raw: 2.61 \pm 0.03 ; cooked: $1.74 \pm 0.03$ ); quercitrin (raw: $5.73 \pm 0.01$; cooked: $5.68 \pm 0.01$ ); apigenin (raw: 2.09 \pm 0.01 ; cooked: $1.79 \pm 0.02$ ), with exception of quercetin (raw: $2.11 \pm 0.02$; cooked: $5.73 \pm 0.02$ ) and caffeic acid (raw: $2.08 \pm 0.04$; cooked $2.95 \pm 0.04$ ). The results of the antioxidant indices of in vitro enzyme digested lima beans revealed higher values for cooked Lima beans compared to the raw counterpart, with a stepwise increase at the different stages of in vitro digestion, with the exception of ferric reducing antioxidant power; TPC (oral digestion: $65.44 \pm 0.96$; gastric digestion: $134.87 \pm 0.46$; intestinal digestion: $517.72 \pm 4.70 ; \mathrm{mg} / \mathrm{g}$ tannic acid equivalent), TFC (oral digestion: $199.30 \pm 6.43$; gastric digestion: $1065.97 \pm 1.22$; intestinal digestion: $3691.87 \pm 4.2 ; \mathrm{mg} / \mathrm{g}$ quercetin equivalent), DPPH (oral digestion: $85800.00 \pm 305.50$; gastric digestion: $99066.66 \pm 115.47$; intestinal digestion: $211354.20 \pm$ $360.84 ; \mu \mathrm{mol} \mathrm{TE} / \mathrm{g}$ sample). The results also revealed a progressive increase in the antioxidant indices and amino acid composition $(\mathrm{mg} / \mathrm{kg})$ for both raw and processed lima beans at various stages of the in vitro digestion, with the intestinal phase of simulated digestion ranking higher. This implied that the Lima beans contained some essential amino acids and antioxidant molecules that would be readily available after passing through the gastrointestinal tract and could therefore be explored as functional food in the management of free radical mediated diseases.
\end{abstract}

Keywords: Antioxidant Activities; Amino Acid Composition; Phenolic Compounds; P. Lunatus; in vitro Digestion 


\section{Introduction}

Plants are the most predominant harvesters of solar energy and they are valuable primary resources of essential nutrients for human food production (Bain et al., 2013; Fanzo, 2015). In common with most developing nations of the world, the state of nutrition in Nigeria is still characterized by inadequate calorie and protein supplies (Babatunde, Adejobi, \& Fakayode, 2010; FAO, 2011). Protein foods and particularly animal protein have continued to be in short supply. Most experts consider protein deficiency as the commonest form of malnutrition in the developing countries, especially in regions where diets are based mainly on roots and tuber crops (FAO, 2013; Trehan \& Manary, 2015). The production of protein-rich foods (leguminous seeds and particularly animal products) has been much less efficient. Therefore, in an attempt to widen the narrow food base, food and agricultural scientists are screening lesser known and under-exploited native plants for possible potential sources of food nutrients (Baldermann et al., 2016).

Grain legumes are grouped into two classes; major and minor species. The major species include the industrial legumes such as soybean, groundnut, common beans (Phaseolus vulgaris), chickenpea (Cicer arietinum), and pea (Pisum sativum). Minor species exist in a wide range of diversity either as cultivated or wild species across various regions of the world and are usually cultivated by the traditional farmers; they are also referred to as neglected, underutilized, under-cultivated or lesser-known legumes (Pastor-Cavada, Juan, Pastor, Alaiz, \& Vioque, 2016). The wild species of the minor grain legumes include kersting groundnut (Kerstingiella geocarpa) and marama bean (Tylosema esculentum). The miscellaneous legumes are the minor grain legumes that have received very little research attention when compared with the major grain legumes such as cowpea and soybean. Leguminous seeds are an important source of proteins, energy and other nutrients in the diets of large population of people around the world; they form an excellent source of lysine, methionine and tryptophan, water-soluble vitamins (riboflavin, niacin and folacin) and of minerals: phosphorus, iron and magnesium (FAO,
2012). Legume seed coats, commonly referred to as hulls, are rich sources of polyphenolics and antioxidants (Iriti \& Varoni, 2017; Pastor-Cavada et al., 2016). A number of studies have shown that legumes are rich in antioxidants, some of these legumes include peanut, lentils and soybean (Zou, Chang, Gu, \& Qian, 2011), Bambara groundnut (Nyau, Prakash, Rodrigues, \& Farrant, 2015), African yam bean, Lima bean (Oboh, Ademiluyi, \& Akindahunsi, 2009), Pigeon pea (Oboh et al., 2009).

Lima bean, P. Lunatus belongs to the family leguminosae and is mostly cultivated in South America (Yellavila, Agbenorhevi, Asibuo, \& Sampson, 2015). Lima beans are sometimes referred to as haba beans, sugar beans, butter beans, Guffin beans, civet beans, Hibbert beans, Pallar beans, Sieva beans, Madagascar beans, and Burma beans. It is one of the underutilized legumes found in Nigeria, though a minor crop; they have been an important source of plant protein to millions of Nigerians and are widely known for their fibre, mineral and protein contents but with a lesser attention to their nutraceutical value (Saleem, Ahmed, \& Hasan, 2016; Yellavila et al., 2015).

The role of medicinal food plants in disease prevention has been attributed to the antioxidant properties of their constituents, usually associated with a wide range of amphipathic molecules, broadly termed polyphenolic compounds (Miguel, 2010; Ozcan, akpinar, YilmazErsan, \& Delikanli, 2014). The protective effects of the dry beans in disease prevention may not be entirely associated with dietary fibre, but to phenolic compounds and other non-nutritive compounds (Miguel, 2010; Oomah, Tiger, Olson, \& Balasubramanian, 2006). Polyphenols from Lima beans will possibly act as antioxidants, hindering the formation of free radicals that eventually lead to the deterioration of biological molecules. These naturally occurring phenolic compounds are predominantly present in the seed coat and possess anti-mutagenic and antioxidant activities (Attree, Du, \& Xu, 2015; Iriti \& Varoni, 2017).

The antioxidant compounds and other phytonutrients present in most legumes have been extracted and measured by different methods (Khang, Dung, Elzaawely, \& Xuan, 2016; Nyau 
et al., 2015; Oboh et al., 2009; Salawu, Bester, \& Duodu, 2014). The results of such experiments clearly demonstrate a range of phytoconstituents with potential antioxidant action, but that cannot be translated to be available phyto-constituents when the legumes are degraded by the enzymes and juices of the gastrointestinal tract during passage through it. Some studies have compared the content of bioactive compounds and antioxidant activities in undigested and digested extracts (Bouayed, Hoffmann, \& Bohn, 2011; Faller, Fialho, \& Liu, 2012; Gimenez, Moreno, Lopez-Caballero, Montero, \& Gomez-Guillen, 2013; Tavares et al., 2012). Hence, the present investigation sought to evaluate the antioxidant activities and the amino acid profile of Lima beans after a stepwise simulated human gastrointestinal digestion.

\section{Materials and Methods}

\subsection{Chemicals}

Follin-Ciocalteu's reagent, tannic acid, sodium carbonate, iron (iii) chloride, potassium ferricyanide, trichloroacetic acid, aluminium chloride, potassium acetate, 2,2- diphenyl1-picrylhydrazyl radical and 6-hydroxy-2, 5,7,8-tetramethylchroman-2-carboxylic acid (Trolox) were obtained from Sigma chemical company, USA. All other chemicals were obtained from standard chemical suppliers and were of analytical grade, while the water used was glass distilled.

\subsection{Sample collection}

Lima beans ( $P$. Lunatus) were obtained from Oba market in Akure, Nigeria. They were identified and authenticated in the Department of Crop, Soil and Pest Management, School of Agriculture and Agricultural Technology, Federal University of Technology, Akure, Ondo state, Nigeria.

\subsection{Sample treatment and preparation}

The sample was divided into two portions; the first portion of the sample (raw) was sorted, washed, air-dried and milled into a powdered form, prior to enzyme treatments of in vitro digestion. While, the second portion was sorted, washed and cooked at $100{ }^{\circ} \mathrm{C}$ for $4 \mathrm{~h}$, cooled, air-dried and then milled prior to the enzyme treatments of in vitro digestion. All the milled samples were stored in plastic containers at room temperature in the Department of Biochemistry, Federal University of Technology, Akure, Nigeria until used.

\section{4 in vitro enzyme digestion}

The in vitro digestion using sequential enzymatic steps was based on a slightly modified method as reported by Delgado-Andrade, Alberto CondeAguilera, Haro, Pastoriza de la Cueva, and Angel Rufian-Henares (2010). Various stages of the gastrointestinal digestion (oral, gastric and total gastrointestinal digestion) were carried out.

\section{Oral digestion}

Ten grams of the milled Lima beans were weighed and dispersed in $200 \mathrm{~mL}$ of distilled water. 32.5 $\mathrm{mg}$ of alpha amylase was dissolved in $25 \mathrm{~mL} 1 \mathrm{mM}$ calcium chloride at $\mathrm{pH} 7.0$, and $1500 \mu \mathrm{l}$ of the alpha amylase was added to each test tube (simulating $\mathrm{pH}$ conditions in the mouth). The tubes were incubated in a shaking water bath set at 37 ${ }^{\circ} \mathrm{C}$ for $40 \mathrm{~min}$ and at 80 strokes/ min. The sample was incubated in boiling water at $100^{\circ} \mathrm{C}$ for 4 min for enzyme inactivation and centrifuged for $60 \mathrm{~min}$ at $4000 \mathrm{x} \mathrm{g}$, then the soluble fraction was kept in the refrigerator for subsequent analysis and the insoluble fraction was discarded. A nonenzymic digest (control) was also done for both raw and cooked samples with the same procedure used for the in vitro enzyme digestion but without the addition of enzymes.

\section{Oral-Gastric digestion}

Ten grams of the milled lima beans were weighed and dispersed in $200 \mathrm{~mL}$ of distilled water. 32.5 
100 Salawu et al.

$\mathrm{mg}$ of alpha amylase was dissolved in $25 \mathrm{~mL} 1 \mathrm{mM}$ calcium chloride at $\mathrm{pH} 7.0$, and $1500 \mu \mathrm{l}$ of the alpha amylase was added to each test tube (simulating $\mathrm{pH}$ conditions in the mouth). The tubes were incubated in a shaking water bath set at $37^{\circ} \mathrm{C}$ for $40 \mathrm{~min}$ and at 80 strokes/ min. The pH was adjusted to 2 after 40 min using concentrated $\mathrm{HCl} .10 \mathrm{mg}$ pepsin which was dissolved in $5 \mathrm{~mL}$ of $0.05 \mathrm{M} \mathrm{HCl}$ was added to each tube (simulating $\mathrm{pH}$ conditions in the stomach). The tubes were incubated in a shaking water bath set at $37^{\circ} \mathrm{C}$ for $40 \mathrm{~min}$ and at 80 strokes/ min. The sample was incubated in boiling water at $100{ }^{\circ} \mathrm{C}$ for 4 min for enzyme inactivation and centrifuged for $30 \mathrm{~min}$ at $4000 \mathrm{x} \mathrm{g}$, then the soluble fraction was kept in the refrigerator for subsequent analysis: the insoluble fraction was discarded. A nonenzymic digest (control) (without enzyme) was also done for both raw and cooked samples with the same procedure used for the in vitro digestion.

\section{Total gastrointestinal digestion}

Ten grams of the milled lima beans were weighed and dispersed in $200 \mathrm{~mL}$ of distilled water. 32.5 $\mathrm{mg}$ of alpha amylase were dissolved in $25 \mathrm{~mL} 1$ $\mathrm{mM}$ calcium chloride at $\mathrm{pH}$ 7.0, and $1500 \mu \mathrm{l}$ of the alpha amylase was added to each test tube (simulating $\mathrm{pH}$ conditions in the mouth). The tubes were incubated in a shaking water bath set at $37^{\circ} \mathrm{C}$ for $40 \mathrm{~min}$ and at 80 strokes/ min. The $\mathrm{pH}$ was adjusted to 2 after $40 \mathrm{~min}$ using concentrated $\mathrm{HCl} .10 \mathrm{mg}$ pepsin, which was dissolved in $5 \mathrm{~mL}$ of $0.05 \mathrm{M} \mathrm{HCL}$, was added to each tube (simulating $\mathrm{pH}$ conditions in the stomach). The tubes were incubated in a shaking water bath set at $37^{\circ} \mathrm{C}$ for $40 \mathrm{~min}$ and at 80 strokes/ min. After 40 min shaking, the $\mathrm{pH}$ was adjusted to 6 using $\mathrm{NaOH}$. After $20 \mathrm{~min}, 50 \mathrm{~mL}$ of pancreatin solution (9 gram of pancreatin in $60 \mathrm{~mL}$ of distilled water), was added in each test tube and the $\mathrm{pH}$ was adjusted finally to 7.5 using $\mathrm{NaOH}$ (simulating $\mathrm{pH}$ conditions in the small small intestine). The sample was incubated in boiling water at $100{ }^{\circ} \mathrm{C}$ for $4 \mathrm{~min}$ for enzyme inactivation and centrifuged for $60 \mathrm{~min}$ at $4000 \mathrm{x}$ g. The soluble fraction was kept in the refrigerator for subsequent analysis and the insoluble fraction was discarded. A non-enzymic digest (control) (without enzyme) was also made for both raw and cooked samples with the same procedure used for the in vitro digestion.

\subsection{Quantification of phenolic compounds by HPLC-DAD}

For analysis of the Lima bean extracts, $10 \mathrm{~mL}$ of the each extract was injected into a Phenomenex $\mathrm{C}_{18}$ column (4.6 mm x $250 \mathrm{~mm}$ ) packed with 5 $\mu \mathrm{m}$ diameter pore size. Mobile phases A and B were Milli-Q water, acidified to $\mathrm{pH} 2.0$ with 1 $\%$ of phosphoric acid and methanol, correspondingly, solvent gradient was used as follows: 0-10 $\min , 5 \% \mathrm{~B} ; 10-25 \min , 15 \% \mathrm{~B} ; 25-40 \mathrm{~min}, 30$ $\%$; 40-55 min $50 \%$ B; 50-65 min $70 \%$ B; $65-80$ min, $100 \% \mathrm{~B}$, following the method described by Omoba, Obafaye, Salawu, Boligon, and Athayde (2015) with slight modifications. The extracts and mobile phase were filtered through a $0.45 \mu \mathrm{m}$ membrane filter (Millipore) and then degassed by ultrasonic bath prior to use. The extract was analyzed at a concentration of $10 \mathrm{mg} / \mathrm{mL}$. The flow rate was $0.6 \mathrm{~mL} / \mathrm{min}$ and the injection volume was $40 \mu \mathrm{L}$. The sample and mobile phase were filtered through a $0.45 \mu \mathrm{m}$ membrane filter (Millipore) and then degassed by ultrasonic bath prior to use. Stock solutions of reference standards were prepared in the HPLC mobile phase at a concentration range of $0.050-0.300 \mathrm{mg} / \mathrm{mL}$. Quantifications were carried out by integration of the peaks using the external standard method, at $254 \mathrm{~nm}$ for gallic acid; $280 \mathrm{~nm}$ for catechin, $327 \mathrm{~nm}$ for caffeic acid, and $365 \mathrm{~nm}$ for rutin, quercitrin, quercetin, kaempferol and apigenin. The chromatography peaks were confirmed by comparing the retention time with those of the reference standards and by DAD spectra (200 to $700 \mathrm{~nm}$ ). All chromatography operations were carried out at ambient temperature and in triplicate. The limit of detection (LOD) and limit of quantification (LOQ) were calculated based on the standard deviation of the responses and the slope using three independent analytical curves. LOD and LOQ were calculated as 3.3 and $10 \delta / \mathrm{S}$, respectively, where $\delta$ is the standard deviation of the response and $\mathrm{S}$ is the slope of the calibration curve (Boligon et al., 2015). 


\subsection{Determination of total phenolic content}

The total phenolic content of the in vitro enzyme digested Lima bean and undigested control samples was determined by the Folin-Ciocalteu assay as described by Mole and Waterman (1994). $500 \mu \mathrm{l}$ of Folin-Ciocalteu reagent was added and mixed with a solution containing $100 \mu \mathrm{L}$ of the extract and $2 \mathrm{~mL}$ of distilled water. $1.5 \mathrm{~mL}$ of 7.5 $\%$ sodium carbonate was then added to the solution and the volume was made up to $10 \mathrm{~mL}$ with distilled water. The mixture was left to stand for $2 \mathrm{~h}$ after addition of the sodium carbonate. The absorbance of the mixture was measured at $760 \mathrm{~nm}$ using a Lambda EZ150 spectrophotometer (Perkin Elmer, USA). The standard used was tannic acid and the results were expressed as $\mathrm{mg}$ tannic acid equivalents per gram of the sample.

\subsection{Determination of total flavonoid content}

The total flavonoid content of the in vitro enzyme digested Lima bean and undigested control samples were determined using a slightly modified method reported by Meda, Lamien, Romito, Millogo, and Nacoulma (2005). Briefly, $0.5 \mathrm{~mL}$ of enzyme digested sample was mixed with $0.5 \mathrm{~mL}$ distilled $\mathrm{H}_{2} \mathrm{O}, 50 \mu \mathrm{L}$ of $10 \% \mathrm{AlCl}_{3}, 50 \mu \mathrm{l}$ of $1 \mathrm{~mol}$ $\mathrm{L}^{-1}$ potassium acetate and $1.4 \mathrm{~mL}$ water, and incubated at room temperature for $30 \mathrm{~min}$. Thereafter, the absorbance of each reaction mixture was measured at $415 \mathrm{~nm}$ using a Lambda EZ150 spectrophotometer (Perkin Elmer, USA). The total flavonoid was calculated using quercetin as standard by making use of a seven point standard curve $(0-100 \mu \mathrm{g} / \mathrm{mL})$. The total flavonoid content of samples was determined in triplicate and the results were expressed as mg quercetin equivalent per gram of the sample.

\subsection{Reducing power assay}

The reducing power of the in vitro enzyme digested Lima bean samples and undigested control were determined by assessing the ability of each extract to reduce $\mathrm{FeCl}_{3}$ solution as described by Oyaizu (1986). Briefly, $1 \mathrm{~mL}$ of the sample was mixed with $1 \mathrm{~mL} 200 \mathrm{mM}$ sodium phosphate buffer ( $\mathrm{pH}$ 6.6) and $1 \mathrm{~mL} 1 \%$ potassium ferricyanide. The mixture was incubated at $50^{\circ} \mathrm{C}$ for $20 \mathrm{~min}$ and then $1 \mathrm{~mL} 10 \%$ trichloroacetic acid (TCA) was added. This mixture was centrifuged at $353 \mathrm{x} \mathrm{g}$ for $10 \mathrm{~min} .2 \mathrm{~mL}$ of the supernatant was mixed with an equal volume of water and 0.4 $\mathrm{mL}$ of $0.1 \%$ ferric chloride. The absorbance was measured at $700 \mathrm{~nm}$ using a Lambda EZ150 spectrophotometer (Perkin Elmer, USA). The ferric reducing antioxidant power was expressed as $\mathrm{mg}$ ascorbic acid equivalent/g of the sample.

\subsection{DPPH radical scavenging assay}

DPPH radical scavenging activity was measured according to the method of Brand-Williams, $\mathrm{Cu}$ velier, and Berset (1995), with some modifications. The stock solution was prepared by dissolving $24 \mathrm{mg}$ DPPH with $100 \mathrm{~mL}$ methanol and then stored at $-20^{\circ} \mathrm{C}$ until needed. The working DPPH solution was obtained by mixing $10 \mathrm{~mL}$ stock solution with $45 \mathrm{~mL}$ methanol to obtain an absorbance of 1.1 units at $515 \mathrm{~nm}$ using the spectrophotometer. $0.5 \mathrm{~mL}$ of the in vitro enzyme digested sample was diluted with $2 \mathrm{~mL}$ of methanol to obtain a mother solution. $150 \mu \mathrm{L}$ of the mother solution were allowed to react with $2850 \mu \mathrm{L}$ of the DPPH working solution for $6 \mathrm{~h}$ in the dark. Then the absorbance was taken at 515 nm using a Lambda EZ150 spectrophotometer (Perkin Elmer, USA). Result was expressed in $\mu \mathrm{mol}$ Trolox equivalent/g sample.

\subsection{Amino acid profile assay}

Amino acid profile was determined according to the method of Obreshkova, Tsvetkova, and Ivanov (2012). In order to ensure that the dried and pulverized undigested (cooked and raw) samples were completely dry, they were dried to constant weight for a period of time in the laboratory. The sample of $10.0 \mathrm{~g}$ was weighed into a 250 $\mathrm{mL}$ conical flask. The sample was defatted with $30 \mathrm{~mL}$ of the petroleum spirit three times with soxhlet extractor that was equipped with thimble. The sample was hydrolyzed three times to ensure complete hydrolysis to achieve total recov- 
ery of amino acids. The pulverized and defatted sample was soaked with $30 \mathrm{~mL}$ of $1 \mathrm{M}$ potassium hydroxide solution and incubated for $48 \mathrm{~h}$ at $110^{\circ} \mathrm{C}$ in a hermetically sealed borosilicate glass container. After the alkaline hydrolysis, the hydrolysate was neutralized to get the $\mathrm{pH}$ in the range 2.5-5.0. The solution was purified by cation-exchange solid-phase extraction. The amino acids in the purified solution were derivatised with ethylchloroformate by the established mechanism, and subsequently injected into the gas chromatograph (GC) for amino acid analysis. The deactivated enzyme digests of raw and cooked samples (digest incubated in boiling water at $100{ }^{\circ} \mathrm{C}$ for $4 \mathrm{~min}$ ), obtained after the total intestinal phase of the in vitro digestion were also injected into the GC for amino acid analysis.

\subsection{Statistical Analysis}

All the analyses were run in triplicate. Results were then computed using Microsoft Excel software (Microsoft Corporation, Redmond, WA) and followed by one-way Anova with Duncan's Multiple Range Test (DMRT) to compare the means that showed significant variation by using SPSS 11.09 for Windows. The significance level was set at $\mathrm{p}<0.05$.

\section{Results and Discussion}

\subsection{Results}

\section{HPLC-DAD Phenolic Characterization}

The HPLC-DAD analysis of phenolic compounds in processed Lima beans (cooked and raw) as shown in Fig. 1, revealed the presence of gallic acid, catechin, caffeic acid, rutin, quercitrin, quercetin, kaempferol and apigenin. The quantitative estimates of these phenolic compounds in Lima beans (Table 1) revealed a slight reduction in the level of some of them (gallic acid, catechin, rutin, quercitrin, apigenin) after cooking, with exception of caffeic acid and quercetin which were higher in the raw Lima beans.

\section{Total Phenolic and Flavoid Content}

The phenolic contents of raw and processed Lima beans at various stages of in vitro digestion were as shown in Fig. 2. The results revealed a slightly higher phenolic content in the enzyme digested cooked beans compared to the raw counterpart. The results also showed a progressive increase in the phenolic content $(\mathrm{mg} / \mathrm{g})$ of the digested Lima beans at each stage of in vitro digestion with the oral phase of digestion showing the least phenolic content (raw: 45.67, cooked: $65.44)$ followed by the oral-gastric phase of digestion (raw: 61.76, cooked: 134.87). The highest phenolic content was recorded after the total gastrointestinal digestion (raw: 439.18, cooked: 517.72). The total flavonoid content of raw and processed Lima beans at various stages of in vitro digestion is shown in Fig. 3. Similarly, the results revealed higher flavonoid content in the enzyme digested cooked beans compared to the raw sample. The results also showed a progressive increase in the total flavonoid content of the digested Lima beans at each stage of in vitro digestion with the oral phase of digestion showing the least total flavonoid content. The higher flavonoid content was recorded after the total gastrointestinal digestion in digested raw and digested cooked Lima beans respectively.

\section{Antioxidant Properties}

The results of the ferric reducing antioxidant power of raw and processed lima beans at various stages of in vitro digestion were as shown in Fig. 4. Conversely, the ferric reducing antioxidant power of the digested raw lima beans was higher than that of the digested cooked lima beans. The DPPH radical scavenging activity of raw and cooked lima beans, at various stages of in vitro digestion was as shown in Fig. 5 . The results also revealed higher DPPH radical scavenging activity in the enzyme digested cooked beans compared to the raw counterpart. Similarly, the results also showed a progressive increase in the ferric reducing power and DPPH radical scavenging activity of the digested Lima beans at each stage of in vitro digestion, with the total phase of the simulated gastro intestinal digestion ranking higher. 
Antioxidant Indices and Amino Acid Composition of Lima Beans After in vitro Digestion | 103

Table 1: Phenolic and flavonoid composition of Lima Bean extracts

\begin{tabular}{lcc}
\hline Compounds & $\begin{array}{c}\text { Raw Lima beans } \\
\mathrm{mg} / \mathrm{g}\end{array}$ & $\begin{array}{c}\text { Cooked Lima beans } \\
\mathrm{mg} / \mathrm{g}\end{array}$ \\
\hline Gallic acid & $1.96 \pm 0.02^{a}$ & $1.82 \pm 0.01^{a}$ \\
Catechin & $0.83 \pm 0.01^{b}$ & $0.73 \pm 0.01^{b}$ \\
Caffeic acid & $2.08 \pm 0.04^{a}$ & $2.95 \pm 0.04^{c}$ \\
Rutin & $2.61 \pm 0.03^{d}$ & $1.74 \pm 0.03^{a}$ \\
Quercitrin & $5.73 \pm 0.01^{e}$ & $5.68 \pm 0.01^{d}$ \\
Quercetin & $2.11 \pm 0.02^{a}$ & $5.73 \pm 0.02^{d}$ \\
Kaempferol & - & $0.81 \pm 0.03^{b}$ \\
Apigenin & $2.09 \pm 0.01^{a}$ & $1.79 \pm 0.02^{a}$ \\
\hline
\end{tabular}

Results are expressed as mean \pm standard deviations (SD) of three determinations.

Means followed by different letters differ significantly by Tukey test at $\mathrm{p}<0.05$
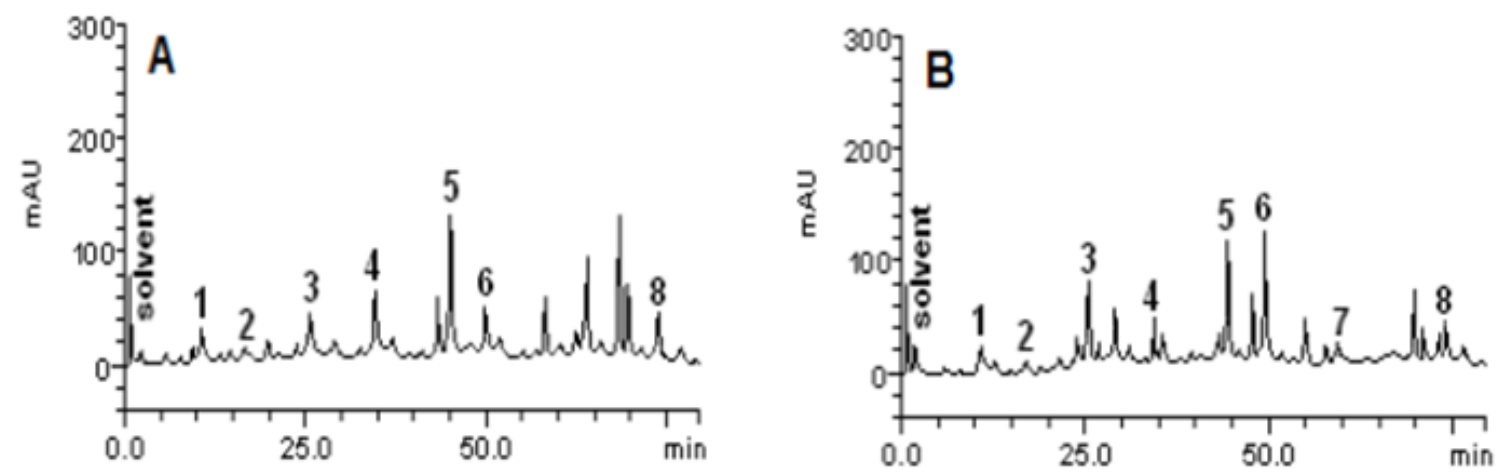

Figure 1: Representative high performance liquid chromatography profile of Lima bean raw (A) and cooked (B) extracts. Gallic acid (peak 1), catechin (peak 2), caffeic acid (peak 3), rutin (peak 4), quercitrin (peak 5), quercetin (peak 6), kaempferol (peak 7) and apigenin (peak 8)

\section{Amino acid Profile}

The amino acid profiles of raw and processed Lima beans at various stages of in vitro digestion were as shown in Table 2 . The results revealed a varied level of glycine, alanine, serine, proline, valine, threonine, isoleucine, leucine, aspartate, lysine, methionine, glutamate, phenylalanine, histidine, arginine, tyrosine, tryptophan and cysteine in the raw and cooked Lima beans respectively. High levels of these amino acids were found after the total intestinal phase of the simulated gastrointestinal digestion in both cooked and raw in vitro digested Lima beans. The results also showed that the in vitro en- zyme digested cooked sample had higher amino acid values than the raw counterpart. It was observed that the process of cooking gave significantly higher amino acid contents compared with the raw counterpart.

\section{Discussion}

Legumes are one of the most important classes of food that have been used as a stable food to provide the proteins and energy requirements of man (Brand, Brandt, \& Cruywagen, 2004). In addition to the provision of nutrients, legumes also contain valuable bioactive compounds such 
104 | Salawu et al.

Table 2: The Amino Acid Profile of Raw and Cooked in vitro Enzyme Digested and Undigested Lima Beans $(\mathrm{mg} / \mathrm{kg})$

\begin{tabular}{|c|c|c|c|c|c|c|c|c|}
\hline Amino Acid & $\mathrm{RP}$ & ORD & OGRD & TDR & $\mathrm{CP}$ & ODC & OGCD & TCD \\
\hline Glycine & $310 \pm 32.4^{f}$ & $0.083 \pm 0.002^{a}$ & $0.15 \pm 0.03^{c}$ & $290 \pm 19.2^{e}$ & $330 \pm 19.4^{h}$ & $0.14 \pm 0.02^{b}$ & $0.29 \pm 0.03^{d}$ & $320 \pm 34.2^{g}$ \\
\hline Alanine & $290 \pm 12.5^{f}$ & $0.096 \pm 0.004^{a}$ & $0.15 \pm 0.05^{c}$ & $270 \pm 15.1^{e}$ & $320 \pm 17.2^{h}$ & $0.11 \pm 0.04^{b}$ & $0.23 \pm 0.05^{d}$ & $310 \pm 12.5^{g}$ \\
\hline Serine & $500 \pm 21.2^{g}$ & $0.10 \pm 0.05^{a}$ & $0.23 \pm 0.04^{c}$ & $440 \pm 21.3^{e}$ & $520 \pm 22.3^{h}$ & $0.17 \pm 0.04^{b}$ & $0.46 \pm 0.03^{d}$ & $490 \pm 43.3^{f}$ \\
\hline Proline & $120 \pm 14.3^{f}$ & $0.012 \pm 0.006^{a}$ & $0.037 \pm 0.02^{c}$ & $82 \pm 4.1^{e}$ & $120 \pm 11.4^{g}$ & $0.029 \pm 0.001^{b}$ & $0.059 \pm 0.002^{d}$ & $87 \pm 6.4^{g f}$ \\
\hline Valine & $500 \pm 21.5^{f}$ & $0.15 \pm 0.03^{a}$ & $0.24 \pm 0.05^{c}$ & $460 \pm 21.3^{e}$ & $510 \pm 17.4^{g}$ & $0.21 \pm 0.03^{b}$ & $0.27 \pm 0.04^{d}$ & $500 \pm 24.3^{f}$ \\
\hline Threonine & $340 \pm 13.3^{g}$ & $0.12 \pm 0.04^{a}$ & $0.21 \pm 0.01^{c}$ & $320 \pm 14.2^{e}$ & $350 \pm 15.2^{h}$ & $0.18 \pm 0.02^{b}$ & $0.24 \pm 0.03^{d}$ & $330 \pm 31.3^{f}$ \\
\hline Isoleucine & $410 \pm 14.1^{f}$ & $0.14 \pm 0.02^{a}$ & $0.19 \pm 0.03^{c}$ & $400 \pm 15.3^{e}$ & $500 \pm 21.3^{h}$ & $0.16 \pm 0.06^{b}$ & $0.23 \pm 0.06^{d}$ & $480 \pm 32.4^{g}$ \\
\hline Leucine & $600 \pm 15.2^{f}$ & $0.17 \pm 0.03^{a}$ & $0.23 \pm 0.01^{c}$ & $570 \pm 20.4^{e}$ & $650 \pm 31.4^{h}$ & $0.19 \pm 0.06^{b}$ & $0.26 \pm 0.05^{d}$ & $640 \pm 18.4^{g}$ \\
\hline Aspartate & $850 \pm 23.6^{g}$ & $0.35 \pm 0.01^{a}$ & $0.44 \pm 0.04^{c}$ & $710 \pm 18.1^{e}$ & $870 \pm 28.5^{h}$ & $0.39 \pm 0.03^{b}$ & $0.50 \pm 0.07^{d}$ & $780 \pm 33.5^{f}$ \\
\hline Lysine & $520 \pm 21.3^{g}$ & $0.17 \pm 0.05^{a}$ & $0.19 \pm 0.03^{c}$ & $410 \pm 12.3^{e}$ & $570 \pm 21.4^{h}$ & $0.19 \pm 0.07^{b}$ & $0.22 \pm 0.04^{d}$ & $500 \pm 41.2^{f}$ \\
\hline Methionine & $75 \pm 4.7^{f}$ & $0.014 \pm 0.003^{a}$ & $0.015 \pm 0.006^{a b}$ & $73 \pm 4.1^{e}$ & $79 \pm 5.5^{g}$ & $0.015 \pm 0.001^{a b}$ & $0.15 \pm 0.03^{c}$ & $70 \pm 8.5^{d}$ \\
\hline Glutamate & $960 \pm 15.6^{f}$ & $0.38 \pm 0.04^{a}$ & $0.42 \pm 0.03^{c}$ & $940 \pm 1.4^{e}$ & $1000 \pm 29.7^{h}$ & $0.40 \pm 0.05^{b}$ & $0.53 \pm 0.02^{d}$ & $930 \pm 27.3^{g}$ \\
\hline Phenylalanine & $420 \pm 17.3^{g}$ & $0.15 \pm 0.03^{a}$ & $0.22 \pm 0.04^{c}$ & $370 \pm 21.4^{e}$ & $440 \pm 12.3^{h}$ & $0.17 \pm 0.03^{b}$ & $0.25 \pm 0.04^{d}$ & $400 \pm 33.4^{f}$ \\
\hline Histidine & $270 \pm 12.4^{f}$ & $0.25 \pm 0.02^{a}$ & $0.31 \pm 0.03^{c}$ & $250 \pm 14.2^{e}$ & $280 \pm 21.4^{g}$ & $0.29 \pm 0.02^{b}$ & $0.36 \pm 0.06^{d}$ & $250 \pm 14.5^{e}$ \\
\hline Arginine & $400 \pm 25.3^{e}$ & $0.13 \pm 0.04^{a}$ & $0.17 \pm 0.05^{c}$ & $400 \pm 13.6^{e}$ & $530 \pm 25.2^{h}$ & $0.15 \pm 0.01^{b}$ & $0.22 \pm 0.03^{d}$ & $470 \pm 23.4^{g}$ \\
\hline Tyrosine & $250 \pm 1.3^{g}$ & $0.055 \pm 0.003^{a}$ & $0.26 \pm 0.03^{c}$ & $230 \pm 10.2^{e}$ & $240 \pm 22.4^{h}$ & $0.08 \pm 0.001^{b}$ & $0.32 \pm 0.06^{d}$ & $210 \pm 19.4^{f}$ \\
\hline Tryptophan & $94 \pm 7.5^{g}$ & $0.11 \pm 0.02^{a}$ & $0.17 \pm 0.01^{c}$ & $73 \pm 5.1^{e}$ & $110 \pm 9.7^{h}$ & $0.12 \pm 0.03^{a b}$ & $0.18 \pm 0.03^{c d}$ & $82 \pm 3.7^{f}$ \\
\hline Cysteine & $100 \pm 9.7^{g}$ & $0.034 \pm 0.005^{a}$ & $0.13 \pm 0.03^{c}$ & $80 \pm 4.3^{e}$ & $100 \pm 8.5^{g}$ & $0.047 \pm 0.002^{b}$ & $0.14 \pm 0.01^{c d}$ & $99 \pm 2.9^{f}$ \\
\hline
\end{tabular}

Abbreviations: RP = Raw dried and powdered; ORD = Oral raw digested; OGRD = Oral and gastric raw digested; TDR $=$ Total

digested raw; $\mathrm{CP}=$ Cooked dried and powdered; ODC $=$ Oral cooked digested; OGDC = Oral and gastric cooked digested;

$\mathrm{TCD}=$ Total cooked digested. Values are given as mean $\pm \mathrm{SE}$ of independent experiments performed in triplicate.

Values are given as mean $\pm \mathrm{SE}$ of independent experiments performed in triplicate. Values with different superscripts

in the same row differ significantly $(\mathrm{P}<0.05)$

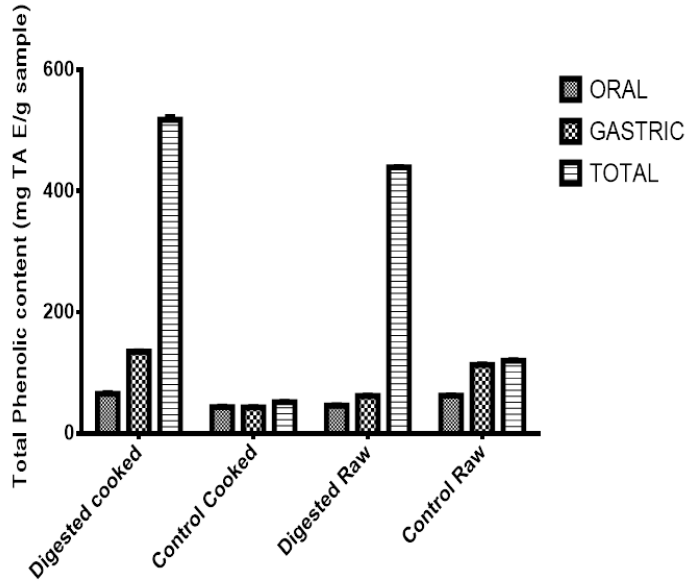

Figure 2: Total phenolic content of $P$. Lunatus extract. The results are expressed as milligrams of tannic acid equivalent (mg TA) per $100 \mathrm{~g}$ of dry weight sample. Value are given as mean $\pm \mathrm{SE}$ of independent experiments performed in triplicate. $\mathrm{TA}=$ Tannic Acid; Oral= Oral digestion; Gastric $=$ Gastric digestion; Total $=$ Total intestinal digestion

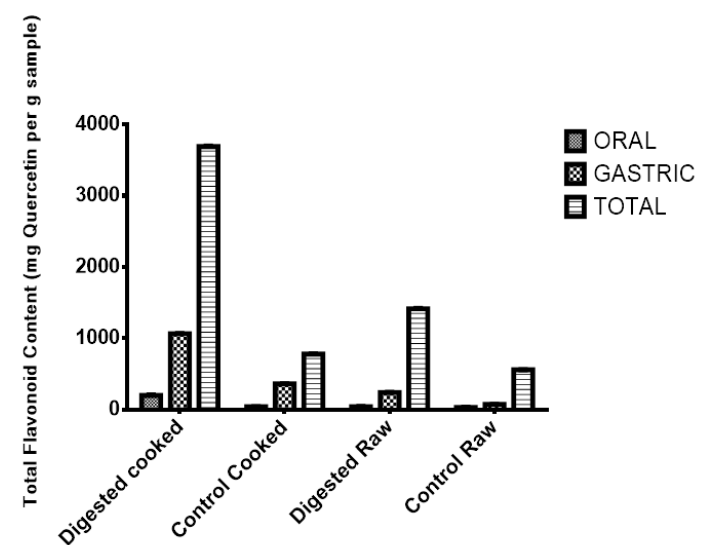

Figure 3: Total flavonoid content of P. Lunatus extract expressed as mg of quercetin equivalents (QE) per $100 \mathrm{~g}$ of dry weight of the sample. Value are given as mean $\pm \mathrm{SE}$ of independent experiments performed in triplicate. Oral $=$ Oral digestion; Gastric $=$ Gastric digestion; Total $=$ Total intestinal digestion 


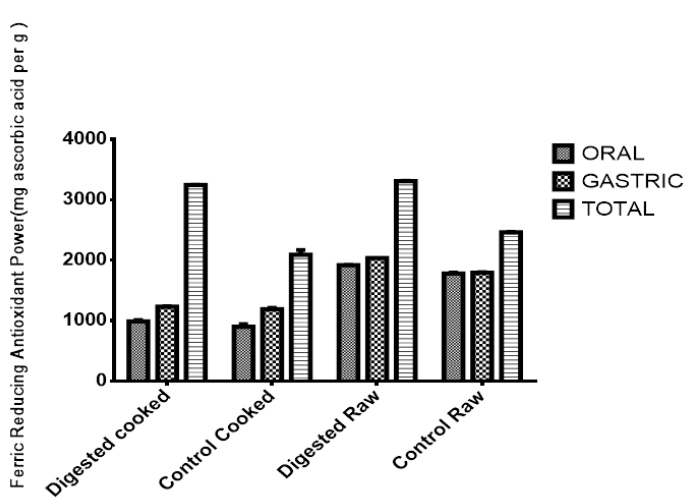

Figure 4: Ferric reducing antioxidant power of $P$. Lunatus extract expressed as milligrams ascorbic acid equivalent per $100 \mathrm{~g}$ of dry weight sample. Value are given as mean $\pm \mathrm{SE}$ of independent experiments performed in triplicate. $\mathrm{AA}=$ Ascorbic Acid; Oral= Oral digestion; Gastric $=$ Gastric digestion; Total=Total intestinal digestion

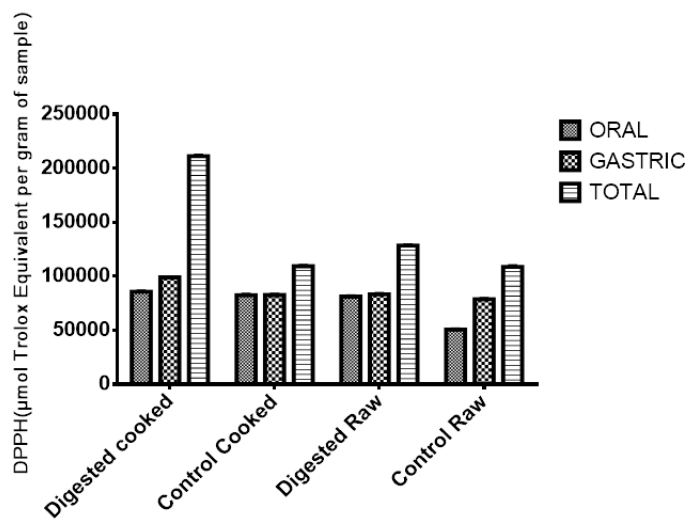

Figure 5: DPPH radical scavenging activity of $P$. Lunatus extract expressed as $\mu$ mole Trolox equivalents per $100 \mathrm{~g}$ of dry weight of the sample. Value are given as mean $\pm \mathrm{SE}$ of independent experiments performed in triplicate. Oral= Oral digestion; Gastric $=$ Gastric digestion; Total $=$ Total intestinal digestion as enzyme inhibitors, lectins, phytates, oxalates, polyphenols, phytosterols and saponins that may help prevent humans developing various diseases. Phenolic compounds constitute an important group of natural products contributing significantly to the medicinal value of a number of food plants (Huang, Cai, \& Zhang, 2010). Studies have focused on the biological activities of phenolic compounds, which have potential antioxidant and free radical scavenging abilities (Lisanti et al., 2016).

Investigations on the phenolic composition of legumes have revealed that legumes are good sources of phenolic compounds with antioxidant activities that can be harnessed in the management of free radical related diseases (Attree et al., 2015; Iriti \& Varoni, 2017). A previous report on the phenolic composition of three varieties of the common bean, (Phaseolus vulgaris L.), soybeans (Glycine max L.), and peas (Pisum sativum L.) from Rwanda revealed the presence of 11 different phenolic compounds in these common beans: gallic acid, (+)-catechin, (-)epicatechin, caffeic acid, o-coumaric acid, chlorogenic acid, quercetin, 4-hydrobenzoic acid, syringic acid, ferulic acid and vanillic acid (Joseph et al., 2014). Catechin was also reported in green beens (Escarpa \& Gonzalez, 2000). In the same vein, a study on the phenolic acids' content of fifteen dry edible bean varieties revealed a high amount of caffeic acid in black beans (Luthria \& Pastor-Corrales, 2006). The phenolic profiles of Phaseolus vulgaris revealed the presence of 13 quercetin-3-O-glycosides, eight kaempferol-3O-glycosides, two myricetin glycosides and four phenolic acids with potential antioxidant activities (Reyes-Martinez et al., 2014).

The reduction in phenolic contents of the Lima beans during cooking could be due to leaching of phenolic compounds in the soaking water. The slight reduction in the level of some of the phenolic compounds after cooking, was in agreement with previous reports, where cooking lowers the total phenolic content of the food materials that were studied (Gujral, Angurala, Sharma, \& Singh, 2011; Han \& Xu, 2014).

Several investigations on common beans highlight their antioxidant potential (Akond et al., 2011; Karamac \& Amarowicz, 2004). Phenolic compounds are widely distributed in the 
plant kingdom and are important in the antioxidant capacity in vitro because of their ability to donate hydrogen and form stable radical intermediates (Scalbert, Manach, Morand, Remesy, \& Jimenez, 2005). The higher total phenolic content of the in vitro digested cooked beans compared with those digested in the raw form may have been due to alterations in the chemical structure and composition as a result of heat during boiling (Han \& Xu, 2014). Thus, cooking might have enhanced the breakdown of the insoluble fibre matrix of the beans thereby making its polyphenols more accessible for further breakdown by the enzymes of the gastro-intestinal tract (Tagliazucchi, Verzelloni, Bertolini, \& Conte, 2010).

The higher phenolic content at the intestinal phase of gastrointestinal digestion was in agreement with previous reports (Ryan \& Prescott, 2010; Wootton-Beard, Moran, \& Ryan, 2011), where a higher phenolic content and antioxidant activity was reported for commercial available juices after the gastric and intestinal phases of gastrointestinal digestion. The higher total flavonoid content of the in vitro digested cooked beans compared with those digested in the raw form may have also been due to alterations in the chemical structure and composition as a result of heat during boiling (Han \& Xu, 2014), thereby making its constituent flavonoids more accessible for further breakdown by the enzymes of the gastro-intestinal tract (Tagliazucchi et al., 2010). The higher total flavonoid content at the intestinal phase of the gastrointestinal digestion was in agreement with previous reports (Ryan \& Prescott, 2010; Wootton-Beard et al., 2011), where a higher polyphenolic content and antioxidant activity was reported for commercially available juices after the gastric and intestinal phases of gastrointestinal digestion.

The decreasing value of the ferric reducing antioxidant power in the cooked lima beans compared to the raw lima beans might have been associated with a quantitative loss of some flavonoids during the heat treatment (Jeong et al., 2004; Salawu, Innocenti, Giaccherini, Akindahunsi, \& Mulinacci, 2008). The higher DPPH radical scavenging activity in the cooked beans of the enzyme digested Lima beans compared to the raw counterpart was in agreement with pre- vious report (Han \& Xu, 2014).

The observed progressive increase in the ferric reducing power and DPPH radical scavenging activity of the digested Lima beans at each stage of in vitro digestion may have been associated with a significantly positive correlation that usually exists between the polyphenolic content and antioxidant activities (Rahman, Khan, Das, \& Hossain, 2016; Ryan \& Prescott, 2010; Sadeghi, Valizadeh, Shermeh, \& Akaberi, 2015; WoottonBeard et al., 2011).

High levels of amino acids found at the total intestinal phase of the simulated gastrointestinal digestion in both cooked and raw in vitro digested lima beans was in agreement with previous reports (Jin, Zhou, Li, Lai, \& Li, 2015), where it was reported that pepsin digestion brings about a marked increase in the free amino acid content of a coconut meat protein hydrolysate by $30.3 \%$ compared to the control and that after digestion with pancreatin, the free amino acid content of a coconut meat protein hydrolysate increased dramatically by 86.7 $\%$ compared to the control. Thus, the maximum amounts of amino acids were released during the total gastrointestinal phase of the simulated in vitro digestion process as a result of the action of the digestive enzymes ( $\alpha$-amylase, pepsin, and pancreatin) of the GIT. This observation was in agreement with a previous report (Tagliazucchi et al., 2010), that suggested that digestion might be a determinant factor in the release of nutritionally relevant compounds from the food matrix. The higher amino acid contents in the cooked Lima beans compared with the raw counterpart was in agreement with previous reports (Lombardi-Boccia, Schlemmer, Cappelloni, \& Di Lullo, 1998; Oluwaniyi, Dosumu, \& Awolola, 2010), where it was reported that the process of boiling generally gives slight but significantly higher amino acid contents respectively compared with the fresh samples.

\section{Conclusions}

The results of this study revealed that Lima beans have a number of health promoting phenolic compounds with antioxidant potential. The results also revealed higher antioxidant indices 
after the intestinal phase of the simulated human digestion. Furthermore, the results also established the availability of a number of essential amino acids after the simulated in vitro digestion, with that of the total intestinal phase of simulated in vitro digestion ranking higher. Therefore, Lima beans could be considered a functional food, with consumption providing a source of nutritionally important amino acids and aiding the prevention of free radical mediated diseases.

\section{Acknowledgements}

Authors would like to acknowledge Universidade Federal de Santa Maria, Centro de Ciências da Saúde, Departamento de Farmácia Industrial, Sala 1115. Campus Camobi. Santa Maria, Rio Grande do Sul. CEP 97105-900 Brasil, for their goodwill to use their facilities to characterize the phenolic compounds present in Lima beans.

\section{References}

Akond, A. S. M. G. M., Khandaker, L., Berthold, J., Gates, L., Peters, K., Delong, H., \& Hossain, K. (2011). Anthocyanin, total polyphenols and antioxidant activity of common bean. American Journal of Food Technology, 6(5), 385-394. doi:10.3923/ ajft.2011.385.394

Attree, R., Du, B., \& Xu, B. (2015). Distribution of phenolic compounds in seed coat and cotyledon, and their contribution to antioxidant capacities of red and black seed coat peanuts (arachis hypogaea 1.) Industrial Crops and Products, 67, 448-456. doi:10. 1016/j.indcrop.2015.01.080

Babatunde, R. O., Adejobi, A. O., \& Fakayode, S. B. (2010). Income and calorie intake among farming households in rural Nigeria: results of parametric and nonparametric analysis. Journal of Agricultural Science, 2(2), 135. doi:10.5539/jas.v2n2p135

Bain, L. E., Awah, P. K., Geraldine, N., Kindong, N. P., Siga, Y., Bernard, N., \& Tanjeko, A. T. (2013). Malnutrition in Sub-Saharan Africa: burden, causes and prospects. Pan
African Medical Journal, 15(1). doi:10. 11604/pamj.2013.15.120.2535

Baldermann, S., Blagojevic, L., Frede, K., Klopsch, R., Neugart, S., Neumann, A., ... Schreiner, M. (2016). Are neglected plants the food for the future? Critical Reviews in Plant Sciences, 35(2), 106-119. doi:10. 1080/07352689.2016.1201399

Boligon, A. A., Piana, M., Kubica, T. F., Mario, D. N., Dalmolin, T. V., Bonez, P. C., ... Athayde, M. L. (2015). HPLC analysis and antimicrobial, antimycobacterial and antiviral activities of Tabernaemontana catharinensis A. DC. Journal of Applied Biomedicine, 13(1), 7-18. doi:10 . 1016/j.jab.2014.01.004

Bouayed, J., Hoffmann, L., \& Bohn, T. (2011). Total phenolics, flavonoids, anthocyanins and antioxidant activity following simulated gastro-intestinal digestion and dialysis of apple varieties: Bioaccessibility and potential uptake. Food Chemistry, 128(1), 14-21. doi:10.1016/j.foodchem.2011.02.052

Brand-Williams, W., Cuvelier, M. E., \& Berset, C. (1995). Use of a free-radical method to evaluate antioxidant activity. Food Science and Technology-lebensmittelwissenschaft \& Technologie, 28(1), 25-30.

Brand, T. S., Brandt, D. A., \& Cruywagen, C. W. (2004). Chemical composition, true metabolisable energy content and amino acid availability of grain legumes for poultry. South African Journal of Animal Science, 34(2), 116-122. doi:10.4314/sajas . v34i2.3815

Delgado-Andrade, C., Alberto Conde-Aguilera, J., Haro, A., Pastoriza de la Cueva, S., \& Angel Rufian-Henares, J. (2010). A combined procedure to evaluate the global antioxidant response of bread. Journal of $\mathrm{Ce}$ real Science, 52(2), 239-246. doi:10.1016/ j.jcs.2010.05.013

Escarpa, A., \& Gonzalez, M. C. (2000). Identification and quantitation of phenolics from green beans by high-performance liquid chromatography. Chromatographia, 52(12), 33-38. doi:10.1007/BF02490789

Faller, A. L. K., Fialho, E., \& Liu, R. H. (2012). Cellular antioxidant activity of feijoada whole meal coupled with an in vitro diges- 
tion. Journal of agricultural and food chemistry, 60(19), 4826-4832.

Fanzo, J. (2015). Ethical issues for human nutrition in the context of global food security and sustainable development. Global Food Security-agriculture Policy Economics and Environment, 7, 15-23. doi:10.1016/j.gfs . 2015.11.001

FAO. (2011). The state of food insecurity in the world. Retrieved from www.fao.org/3/ai2330e.pdf

FAO. (2012). The state of food insecurity in the world. Retrieved from www.fao.org/3/ai3027e.pdf

FAO. (2013). Women, men and nutrition.

Gimenez, B., Moreno, S., Lopez-Caballero, M. E., Montero, P., \& Gomez-Guillen, M. C. (2013). Antioxidant properties of green tea extract incorporated to fish gelatin films after simulated gastrointestinal enzymatic digestion. $L W T$ - Food Science and Technology, 53(2), 445-451. doi:10.1016/j.lwt.2013.03.020

Gujral, H. S., Angurala, M., Sharma, P., \& Singh, J. (2011). Phenolic content and antioxidant activity of germinated and cooked pulses. International Journal of Food Properties, 14(6), 1366-1374. doi:10 . 1080/ 10942911003672167

Han, S., \& Xu, B. (2014). Bioactive components of leafy vegetable edible amaranth (Amaranthus mangostanus 1.) as affected by home cooking manners. American Journal of Food Science and Technology, 2(4), $122-127$.

Huang, W.-Y., Cai, Y.-Z., \& Zhang, Y. (2010). Natural phenolic compounds from medicinal herbs and dietary plants: Potential use for cancer prevention. Nutrition and Cancer-an International Journal, 62(1), 120. doi:10.1080/01635580903191585

Iriti, M., \& Varoni, E. M. (2017). Pulses, healthy, and sustainable food sources for feeding the planet. International Journal of Molecular Sciences, 18(2). doi:10.3390/ijms18020255

Jeong, S. M., Kim, S. Y., Kim, D. R., Jo, S. C., Nam, K. C., Ahn, D. U., \& Lee, S. C. (2004). Effect of heat treatment on the antioxidant activity of extracts from citrus peels. Journal of Agricultural and
Food Chemistry, 52(11), 3389-3393. doi:10. 1021/jf049899k

Jin, B., Zhou, X., Li, B., Lai, W., \& Li, X. (2015). Influence of in vitro digestion on antioxidative activity of coconut meat protein hydrolysates. Tropical Journal of Pharmaceutical Research, 14(3), 441-447. doi:10. 4314/tjpr.v14i3.12

Joseph, O., Phelomene, M., Helene, N., Valens, H., Patrick, O. M., Thavarajah, D., \& Thavarajah, P. (2014). Phenolic compound profiles of two common beans consumed by rwandans. American Journal of Plant Sciences, 5(20), 2943-2947. doi:10.4236/ajps. 2014.520310

Karamac, M., \& Amarowicz, R. (2004). Antioxidant activity of phenolic fractions of white bean (phaseolus vulgaris). Journal of Food Lipids, 11 (2), 165-177. doi:10.1111/j.17454522.2004.tb00268.x

Khang, D. T., Dung, T. N., Elzaawely, A. A., \& Xuan, T. D. (2016). Phenolic profiles and antioxidant activity of germinated legumes. Foods, 5(2). doi:10.3390/foods5020027

Lisanti, A., Formica, V., Ianni, F., Albertini, B., Marinozzi, M., Sardella, R., \& Natalini, B. (2016). Antioxidant activity of phenolic extracts from different cultivars of italian onion (Allium cepa) and relative human immune cell proliferative induction. Pharmaceutical Biology, 54(5), 799-806.

Lombardi-Boccia, G., Schlemmer, U., Cappelloni, M., \& Di Lullo, G. (1998). The inhibitory effect of albumin extracts from white beans (phaseolus vulgaris 1.) on in vitro iron and zinc dialysability: Role of phytic acid. Food Chemistry, 63(1), 1-7. doi:10.1016/S0308-8146(97)00244-6

Luthria, D. L., \& Pastor-Corrales, M. A. (2006). Phenolic acids content of fifteen dry edible bean (phaseolus vulgaris l.) varieties. Journal of Food Composition and Analysis, 19(2-3), 205-211. doi:10.1016/j.jfca.2005. 09.003

Meda, A., Lamien, C. E., Romito, M., Millogo, J., \& Nacoulma, O. G. (2005). Determination of the total phenolic, flavonoid and proline contents in burkina fasan honey, as well as their radical scavenging activity. 
Antioxidant Indices and Amino Acid Composition of Lima Beans After in vitro Digestion |109

Food Chemistry, 91(3), 571-577. doi:10 . 1016/j.foochem.2004.10.006

Miguel, M. G. (2010). Antioxidant activity of medicinal and aromatic plants. a review. Flavour and Fragrance Journal, 25(5), 291-312. doi:10.1002/ffj.1961

Mole, S., \& Waterman, S. (1994). Analysis of phenolic plant metabolites. Blackwell Scientific Publications.

Nyau, V., Prakash, S., Rodrigues, J., \& Farrant, J. (2015). Antioxidant activities of bambara groundnuts as assessed by frap and dpph assays. American Journal of Food and Nutrition, 3, 7-11.

Oboh, G., Ademiluyi, A. O., \& Akindahunsi, A. A. (2009). Changes in polyphenols distribution and antioxidant activity during fermentation of some underutilized legumes. Food Science and Technology International, 15(1), 41-46. doi:10.1177/ 1082013208101022

Obreshkova, D., Tsvetkova, D. D., \& Ivanov, K. (2012). Simultaneous identification and determination of total content of aminoacids in food supplements-tablets by gas chromatography. 5, 57-68.

Oluwaniyi, O. O., Dosumu, O. O., \& Awolola, G. V. (2010). Effect of local processing methods (boiling, frying and roasting) on the amino acid composition of four marine fishes commonly consumed in nigeria. Food Chemistry, 123(4), 1000-1006. doi:10. 1016/j.foodchem.2010.05.051

Omoba, O. S., Obafaye, R. O., Salawu, S. O., Boligon, A. A., \& Athayde, M. L. (2015). Hplc-dad phenolic characterization and antioxidant activities of ripe and unripe sweet orange peels. Antioxidants, 4 (3), 498-512. doi:10.3390/antiox4030498

Oomah, B. D., Tiger, N., Olson, M., \& Balasubramanian, P. (2006). Phenolics and antioxidative activities in narrow-leafed lupins (lupinus angustifolius 1.) Plant Foods for Human Nutrition, 61(2), 91-97. doi:10 . 1007/s11130-006-0021-9

Oyaizu, M. (1986). Studies on products of browning reaction: Antioxidative activity of products of browning reaction prepared from glucosamine. Japanese Journal of Nutrition, 40, 307-316.
Ozcan, T., akpınar, A., Yilmaz-Ersan, L., \& Delikanli, B. (2014). Phenolics in human health. 5, 393-396.

Pastor-Cavada, E., Juan, R., Pastor, J. E., Alaiz, M., \& Vioque, J. (2016). A comprehensive approach to antioxidant activity in the seeds of wild legume species of tribe fabeae. Journal of Botany, 1-6. Retrieved from http://search.ebscohost.com/login. aspx ? direct $=$ true $\&$ AuthType $=$ ip, uid $\&$ $\mathrm{db}=\mathrm{a} 9 \mathrm{~h} \& \mathrm{AN}=114319915 \&$ site $=$ eds-live $\&$ scope $=$ site\&authtype $=$ ip, cookie, uid

Rahman, M. M., Khan, F. E., Das, R., \& Hossain, M. A. (2016). Antioxidant activity and total phenolic content of some indigenous fruits of bangladesh. International Food Research Journal, 23(6), 2399-2404.

Reyes-Martinez, A., Almaraz-Abarca, N., Gallardo-Velazquez, T., del Socorro Gonzalez-Elizondo, M., Herrera-Arrieta, Y., Pajarito-Ravelero, A., ... Isabel Torres-Moran, M. (2014). Evaluation of foliar phenols of 25 mexican varieties of common bean (phaseolus vulgaris 1.) as antioxidants and varietal markers. Natural Product Research, 28(23), 2158-2162. doi:10.1080/14786419.2014.930855

Ryan, L., \& Prescott, S. L. (2010). Stability of the antioxidant activity of twenty-five commercially available fruit juices subjected to an in vitro digestion. International Journal of Food Science \&3 Technology, 45 (6), 11911197. doi:10.1111/j.1365-2621.2010.02254. x. eprint: https://onlinelibrary.wiley.com/ doi/pdf/10.1111/j.1365-2621.2010.02254.x

Sadeghi, Z., Valizadeh, J., Shermeh, O. A., \& Akaberi, M. (2015). Antioxidant activity and total phenolic content of boerhavia elegans (choisy) grown in baluchestan, iran. Avicenna Journal of Phytomedicine, 5(1), 19.

Salawu, S. O., Bester, M. J., \& Duodu, K. G. (2014). Phenolic composition and bioactive properties of cell wall preparations and whole grains of selected cereals and legumes. Journal of Food Biochemistry, 38(1), 62-72. doi:10.1111/jfbc.12026

Salawu, S. O., Innocenti, M., Giaccherini, C., Akindahunsi, A. A., \& Mulinacci, N. (2008). Phenolic profiles of four processed 
tropical green leafy vegetables commonly used as food. Natural Product Communications, 3(12), 2043-2048.

Saleem, Z. M., Ahmed, S., \& Hasan, M. M. (2016). Phaseolus lunatus linn: Botany, medicinal uses, phytochemistry and pharmacology. World Journal of Pharmacy and Pharmaceutical Sciences, 5(11), 87-93.

Scalbert, A., Manach, C., Morand, C., Remesy, C., \& Jimenez, L. (2005). Dietary polyphenols and the prevention of diseases. Critical Reviews in Food Science and $\mathrm{Nu}$ trition, 45(4), 287-306. doi:10 . 1080/ 1040869059096

Tagliazucchi, D., Verzelloni, E., Bertolini, D., \& Conte, A. (2010). In vitro bio-accessibility and antioxidant activity of grape polyphenols. Food Chemistry, 120(2), 599-606. doi:10.1016/j.foodchem.2009.10.030

Tavares, L., Figueira, I., Macedo, D., McDougall, G. J., Leirao, M. C., Vieira, H. L. A., ... Santos, C. N. (2012). Neuroprotective effect of blackberry (rubus sp.) polyphenols is potentiated after simulated gastrointestinal digestion. Food Chemistry, 131 (4), 1443-1452. doi:10.1016/j.foodchem.2011. 10.025

Trehan, I., \& Manary, M. J. (2015). Management of severe acute malnutrition in low-income and middle-income countries. Archives of Disease in Childhood, 100(3), 283-287. doi:10.1136/archdischild-2014306026

Wootton-Beard, P. C., Moran, A., \& Ryan, L. (2011). Stability of the total antioxidant capacity and total polyphenol content of 23 commercially available vegetable juices before and after in vitro digestion measured by frap, dpph, abts and folin-ciocalteu methods. Food Research International, 44(1), 217-224. doi:https:// doi.org/10.1016/j.foodres.2010.10.033

Yellavila, S. B., Agbenorhevi, J. K., Asibuo, J. Y., \& Sampson, G. Y. (2015). Proximate composition, minerals content and functional properties of five lima bean accessions. Journal of Food Security.

Zou, Y., Chang, S. K. C., Gu, Y., \& Qian, S. Y. (2011). Antioxidant activity and phenolic compositions of lentil (lens culinaris var. morton) extract and its fractions. Journal of Agricultural and Food Chemistry, 59(6), 2268-2276. doi:10.1021/jf104640k 